\title{
KEILMUAN HUKUM ISLAM DALAM PERSPEKTIF EPISTEMOLOGIS
}

\author{
Idri*
}

\begin{abstract}
A bstract: This paper is aimed at exploring the epistemological aspect of the science of Islamic Law, that is, its methods and procedures of analysis. For this purpose, the paper makes use of the deductive-coherency method, inductive-correspondence method, scientific method, phenolmenological method, and functional as well structural method. The paper argues that procedures in studying Islamic Law consists of there levels of analysis, namely taxonomy analysis, competence analysis and information processing. In reading Islamic Law in this way, it is hoped that this science may be developed along side with other social sciences and humanities.
\end{abstract}

Keywords: science, Islamic Law, method, analysis, study

\section{Pendahuluan}

Istilah hukum Islam tidak dikenal dalam literatur ilmu keislaman klasik. Tidak ditemukan kata ini baik dalam al-Q ur'an, hadith, kitab-kitab fiqih, maupun usjlıfigh. Istilah yang banyak digunakan dalam beberapa literatur adalah al-hykm, hykm Allâh, shari'gh, hykm shar'i, alshari'gh al-Islamiyah, al-tashri'>al-Islami> dan lain-lain. Abd al-Wahhab Khallaf, misalnya, menyebut hukum Islam sebagai al-h $\mu \mathrm{km}$ al-shar' i $\gg$ Dari sekian banyak istilah itu ternyata tidak ditemukan istilah hukum Islam. Istilah ini terambil dari kata fiqh yang secara bahasa berarti memahami, menguasai, dan mengetahui sesuatu. ${ }^{2}$ Kalaupun ditemukan istilah al-h $\psi k$ km al-Islami> dalam beberapa literatur, tidak dimaksud hukum Islam sebagaimana dipahami di Indonesia, melainkan digunakan untuk pemerintahan Islam seperti halnya al-hykm al-Amawi łpemerintahan Umayah), al-h «k km al-Abbasi łpemerintahan Abbasiyah). Derivasi kata hukum Islam tampaknya lebih sesuai dengan Islamic Law atau Islamic J urispridence dalam bahasa Inggris. Menurut Subhi Mahmasani, Islamic jurisprudence dealt with questions of religion and acts of worship, and with legal transactions, along with all provisions, rules, and particulars derived from them. ${ }^{3}$

Meskipun tidak bisa dipahami secara sendiri-sendiri, karena hukum Islam merupakan satu kata yang untuk memahaminya tak dapat dipisahkan, kata hukum Islam dapat ditelaah dari akar kata al-h $\mu \mathrm{km}$. Kata al-h $\mu \mathrm{km}$, secara bahasa berarti mengadili, memerintah, kembali, peraturan, pemerintahan, dan sebagainya. ${ }^{4}$ Menurut istilah, hukum dapat diartikan dengan dua pengertian. Pertama, ulama Usłl |menyatakan bahwa hukum Islam adalah ketentuan Shax' (Allah dan Rasul-Nya) yang berhubungan dengan perbuatan mukallaf baik berupa tuntutan, pilihan, maupun ketetapan. ${ }^{5}$ Menurut definisi ini, yang dimaksud hukum Islam adalah nas\$yang darinya

* Fakultas Syari'ah IAIN Sunan Ampel Surabaya

1 'A bd al-Wahhab Khallaf, 'Ilm Uskllsal-Fiqh (B eirut: Dasal-Q alam, 1978), 100.

${ }^{2}$ Abu※adl J amal al-Din, Lisan al-'A rab, jilid XIII (Beirut: Dasal-Kutub al-'Ilmiyah, tth.), 522.

3Subhi Mahmasani "A daptation of Islamic J urisprudence to Modern Social N eeds" dalam J ohn J . Donohue dan J ohn L. Esposito (ed.), Islam in Transition Muslim Perspectives (New York: Oxford University Press, 1982), 181.

${ }^{4}$ Louis Ma'luf, al-M unjid (B eirut: Matha'ah al-Katulikiłah, tth.), 146.

5 ‘A bd al-Wahhab Khallaf, 'Ilm Usyll, 100. 
keluar ketentuan-ketentuan hukum. Kedua, para fuqaha'>mendefinisikan hukum Islam dengan akibat yang dituntut oleh ketentuan (firman) Shar'‘ pada suatu perbuatan seperti wajib, haram, dan mubah. ${ }^{6}$ Istilah wajib, haram, atau mubah menurut definisi ini merupakan hukum dalam perspektif fuqaha'> O rang mengatakan bahwa hukum słlat lima waktu wajib, hukum jual beli mubah, hukum mencuri haram.

J ika hukum Islam dipahami sebagai fiqh, maka di kalangan ulama Usłl pengertian pula. Pertama, ilmu tentang hukum-hukum shara' praktis yang diperoleh dari dalildalil yang terperinci. ${ }^{7}$ Definisi ini menunjuk pada figh sebagai epistemologi hukum Islam. Kedua, sekumpulan hukum-hukum shara' praktis yang diperoleh dari dalil-dalil yang terperinci. ${ }^{8}$ Definisi ini menunjuk fiqh sebagai koleksi hukum Islam.

Hukum Islam sebagai hasil ubahsuai dari kata figh adalah sebuah frasa yang termasuk kategori frasa atributif, ${ }^{9}$ terdiri dari kata hukum dan Islam. Salah satu definisi menyatakan bahwa hukum adalah seperangkat peraturan yang ditetapkan oleh pemangkunya dan bersifat mengikat secara multilateral bagi warganya sebagai jaminan sosial yang efektif guna mewujudkan keadilan. ${ }^{10}$ Istilah Islam antara lain didefinisikan dengan agama yang ajaran-ajarannya diwahyukan Tuhan kepada masyarakat manusia melalui Nabi Muhammad sebagai Rasul-Nya. ${ }^{11}$ Dari definisi dua kata tersebut dapat dinyatakan bahwa hukum Islam adalah seperangkat peraturan tentang perbuatan manusia yang ditetapkan oleh pemangkunya berdasarkan wahyu Tuhan yang mengikat masyarakat muslim guna mewujudkan keadilan.

Ketika memasuki wilayah keilmuan, hukum Islam tidak semata sebagai firman (ketentuan dan tuntutan) Allah atau sekumpulan aturan yang berkenaan dengan perbuatan mukallaf, atau seperangkat aturan tentang perbuatan manusia sebagaimana dijelaskan di atas. Sebagai bagian dari keilmuan umumnya, keilmuan hukum Islam harus memenuhi sebagian dari syarat-syarat ilmiah, memiliki sekelompok prinsip yang melalui kajian yang sistematis dilakukan berulangkali telah teruji kebenarannya. Keilmuan hukum Islam disusun sitematis dengan menggunakan kekuatan pemikiran dan penalaran, yang selalu diperiksa dan ditelaah dengan kritis.

\section{Metode Analisis Keilmuan Hukum Islam}

Kajian keilmuan hukum Islam dapat dilakukan setidaknya dengan menggunakan lima metode dan paradigma berpikir, yaitu metode deduktif-koherensi, metode induktif-korespondensi, metode ilmiah, metode fenomenologis, atau metode struktural fungsional. Metode deduksi merupakan metode untuk kajian keilmuan hukum Islam yang dimulai dari dalil-dalil umum dan diaplikasikan pada kasus-kasus spesifik lalu disimpulkan. Metode induktif dimulai dari kasuskasus spesifik keilmuan hukum Islam yang kemudian ditarik kesimpulan yang bersifat umum. Metode ilmiah merupakan metode untuk kajian terhadap peristiwa atau konsep hukum Islam

\footnotetext{
${ }^{6}$ Ibid.

${ }^{7}$ Ibid., 11.

${ }^{8}$ Ibid.

${ }^{9}$ Frasa atributif adalah frasa yang berfungsi mensifati, yaitu kata kedua menjadi sifat dari kata pertama. Maka hukum Islam artinya hukum yang bersifat Islami atau digali dari nilai-nilai Islam.

${ }^{10}$ Lihat: G eorges Gurvitch, Sosiologi H ukum, terjemahan (J akarta: Bharata, 1988), 51.

${ }^{11}$ Harun Nasution, Islam Ditinjau dari Berbagai Aspeknya, J ilid I (J akarta: UI Press, 1985), 24.
} 
dengan menggunakan langkah-langkah dalam kajian pengetahuan ilmiah, biasanya sebagai gabungan antara metode induktif dan deduktif. Metode fenomenologis merupakan metode yang menekankan keilmuan hukum Islam sebagai fenomena hukum atau fenomena sosial. Metode struktural fungsional adalah metode keilmuan hukum Islam yang telah terinternalisasi dalam masyarakat muslim, menjadi norma dan bagian dari pola hidup mereka. Hukum telah masuk dalam wilayah lembaga dan pranata sosial dan memainkan peran yang cukup signifikan.

Tawaran metode-metode di atas karena, sebagai disinyalir al-Faruqi, terdapat kesan bahwa metode-metode tradisional tidak cukup untuk pengkajian keilmuan Islam dikarenakan: Pertama, adanya kecenderungan pembatasan lapangan ijtihad ke dalam penalaran legalistik yakni dimasukkannya problem-problem modern di bawah kategori-kategori legal sehingga dengan cara demikian mereduksi mujtahid kepada faqih (jurist) dan mereduksi ilmu ke dalam fiqih. Kedua, penghilangan seluruh kriteria dan standar rasional dengan menggunakan metodologi yang murni intuitif dan esoteris. ${ }^{12}$ Meskipun alasan kedua masih perlu dikaji lebih lanjut, mengingat tidak seluruh standar rasional dihilangkan sebagaimana diaplikasikan al-Shafi' imelalui metode deduksinya, yang jelas perlu dilakukan analisis metodologis tentang kemungkinankemungkinan metode yang dapat digunakan.

1. Metode Deduksi-Koherensi

Metode deduksi-koherensi - yang dalam kajian Usyll>Fiqh dapat disamakan dengan metode istidlal>dan istinbaty - bergerak dari general kepada partikular, dari konsep yang bersifat umum kepada hal-hal spesifik kemudian ditarik kesimpulan. Metode ini banyak digunakan oleh ulama UsylbFiqh dengan menempatkan nas\$/sebagai sumber hukum yang darinya ditetapkan banyak ketentuan-ketentuan atau ketetapan-ketatapan hukum. Analisis yang digunakan biasanya berupa analisis tekstual, yang berupa aturan-aturan inferensi langsung. Al-Shafi' i>misalnya mengidentifikasi dua sumber pengetahuan utama; pengetahuan yang terdapat dalam teks wahyu (nas\$) dan pengetahuan deduktif (istinbat). ${ }^{13}$

Prosedur untuk kajian ini dapat dilakukan dengan bayan (klarifikasi) dan qiyas(analogi). Pengetahuan yang dihasilkan melalui aplikasi dua prosedur tersebut, menurut al-Shafi' i> selanjutnya diklasifikasi menjadi dua kategori; ijma'>(konsensus) dan ikhtilaf(perselisihan). ljma'smerupakan pengetahuan yang didasarkan pada kesepakatan komunitas ilmiah dan ikhtilaf menunjukkan wilayah pengetahuan yang diperselisihkan. Dengan munculnya pengetahuan yang didasarkan pada komunitas ilmiah, maka ada empat sumber pengetahuan (sebagai dasar deduksi - pen.), yaitu nas\$, $\$$ l-Q $\mathbf{Q}$ ur'an, sunnah, qiyas, dan ijma'. ${ }^{14}$

Analisis tekstual yang terhadap nas\$,jpada kategori bayan (kejelasan) dapat dilihat dari segi mubayyan, zahir, mujmal, nas \$3 mufassar, muhkam, khafi>mushkil, mutashabih, dan sebagainya. M elalui analisis terhadap makna dan maksud teks dilakukan penalaran hukum. Metode deduksi-koherensi ini dapat digunakan dalam kajian keilmuan hukum Islam dengan aturan dan tata cara di atas. Metode deduksi didasarkan pada postulat bahwa kebenaran hukum Islam sebenarnya sudah ada, yaitu dalam ketentuan dalil al-Q ur'an atau ha्adith Nabi.

\footnotetext{
${ }^{12}$ Ismail R. al-Faruqi, Islamization of Knowledge: General Principles and Work Plan (Herdon: VAIIT, 1987), 19.

${ }^{13}$ Muhammad bin Idris al-Shafi'i $>$ al-R isalah (Beirut: Dasal-Kutub al-'Ilmiyah, tth. ), 19.

${ }^{14} \mathrm{lbid}$., 40.
} 
Pikiran manusia dapat mengetahui ide tentang kebenaran tersebut namun tidak menciptakannya dan tidak pula mempelajarinya lewat pengalaman. Dengan kata lain, ide tentang hukum Islam, yang menjadi dasar bagi pengetahuan, diperoleh lewat berpikir secara rasional yang diperoleh dari wahyu, terlepas dari pengalaman manusia. Sistem pengetahuan dibangun secara koheren di atas landasan-landasan pernyataan yang sudah pasti. Metode yang digunakan bersifat deduktif-koherensi sebagaimana pada gambar berikut:

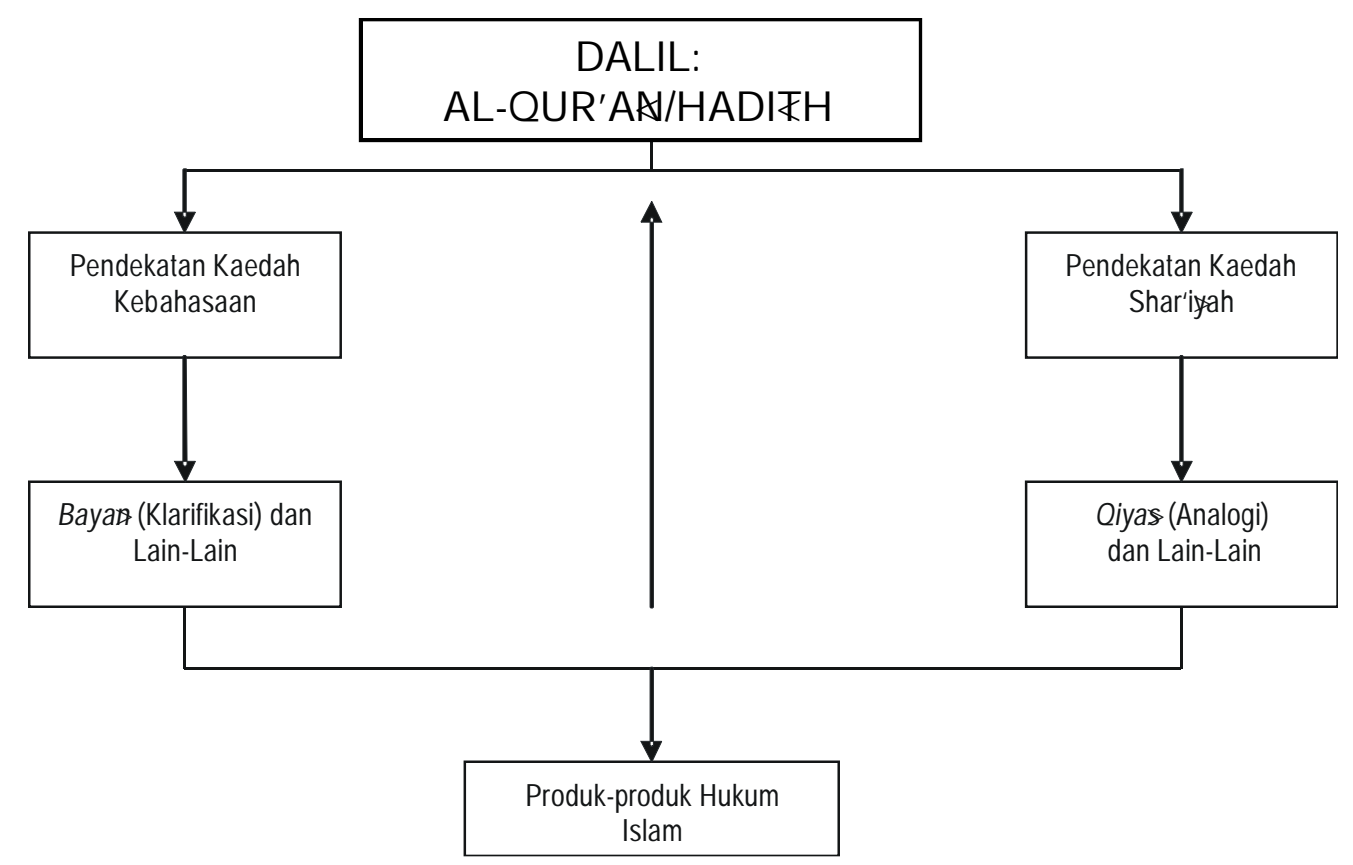

Gambar 1 : Metode Deduksi Koherensi dalam Kajian Keilmuan Hukum Islam

Gambar di atas menunjukkan bahwa kajian keilmuan hukum Islam dengan menggunakan metode deduksi-korespondensi dilakukan berdasar dalil baik al-Qur'an maupun haditith yang dianalisis melalui pendekatan kaedah-kaedah kebahasaan dan kaedah-kaedah shar'iyah. Melalui pendekatan kebahasaan muncullah kemudian beberapa metode istinbaty hukum seperti bayan, zahir, mujmal, nas \$; mufassar, muhkam, khafi, >mushkil, mutashabih, dan sebagainya, sedangkan pendekatan shar'izah berkenaan dengan qiyas, istihsan, istisljah, istish 犺, sadd al-dhari'gh, 'urf, madhhab sahłbi shar' man qablana,dan 'amal ahl al-madinah. Melalui pendekatan dan metode-metode di atas kemudian dihasilkan produk-produk hukum Islam baik yang disepakati oleh para ulama maupun yang diperselisihkan. Dengan demikian, secara epistemologis, keilmuan hukum Islam dapat diketahui melalui pemikiran terhadap dalil-dalil baik al-Qur'an maupun hadith Nabi yang dilakukan melalui ijtihad terhadap ayatayat atau hadith-hadith hukum, dengan metode istinbattertentu, yang kemudian melahirkan produk-produk hukum berupa fiqih. Ijtihad demikian disebut dengan ijtihad istinbaty yaitu ijtihad yang dilakukan melalui nas\$sharisah dengan meneliti dan menyimpulkan ide hukum yang terkandung dalam nas $\$$;

2. Metode Induksi-Korespondensi

Metode induksi yang dikenal dengan metode istiqra'smerupakan metode yang dimulai dari kasus-kasus khusus yang berupa peristiwa-peristiwa hukum yang ditinjau berdasarkan 
ketentuan-ketentuan umum dalam rangka untuk mencapai suatu kesimpulan hukum. ${ }^{15} \mathrm{~J}$ ika sifat koheren menggunakan pola pikir secara deduktif, maka sifat koresponden dalam mencari kebenaran ilmiah menggunakan pola pikir induktif, yaitu meto de berpikir yang dimulai dari hal-hal yang bersifat khusus kemudian ditarik pada hal-hal yang bersifat umum berupa kesimpulan. Dengan kata lain, korespondensi berdasar pada data empirik di lapangan yang kemudian dibuatkan pernyataan-pernyataan yang berisifat umum yang disebut kesimpulan. Dalam penelitian lapangan (field research), baik pola pikir induktif maupun sifat koresponden banyak digunakan karena kesimpulan yang diperoleh, baik yang didahului dengan hipotesis maupun tidak, sangat tergantung pada data empirik yang bersifat khusus itu. Hal-hal yang bersifat kongkrit di lapangan empirik dapat diabstraksi dalam bentuk konsep dan teori. Teori dan konsep dalam ilmu pengetahuan dapat berkembang baik melalui penelitian maupun pemikiran rasional.

Metode ini digunakan dalam kajian hukum Islam tidak sama persis dengan metode induksi-korespondensi pengetahuan ilmiah umumnya karena pernyataan-pernyataan umum sebagai generalisasi dari peristiwa-peristiwa partikular tidak diperoleh dari pengambilan kesimpulan dari data di lapangan, tetapi dikaitkan terlebih dahulu dengan teks nas\$,al-Qur'an atau hadith. Metode induksi ini dapat digunakan pada keilmuan hukum Islam sebagai suatu disiplin yang dinalisis secara ilmiah. Melalui kajian terhadap materia-materia keilmuan hukum Islam yang beragam sesuai dengan disiplin masing-masing ragam ditarik suatu generalisasi yang kemudian dijadikan sebagai kesimpulan. Kesimpulan dapat menjadi teori keilmuan hukum Islam, jika benar-benar didukung data tersebut. Selanjutnya perhatikan gambar berikut:

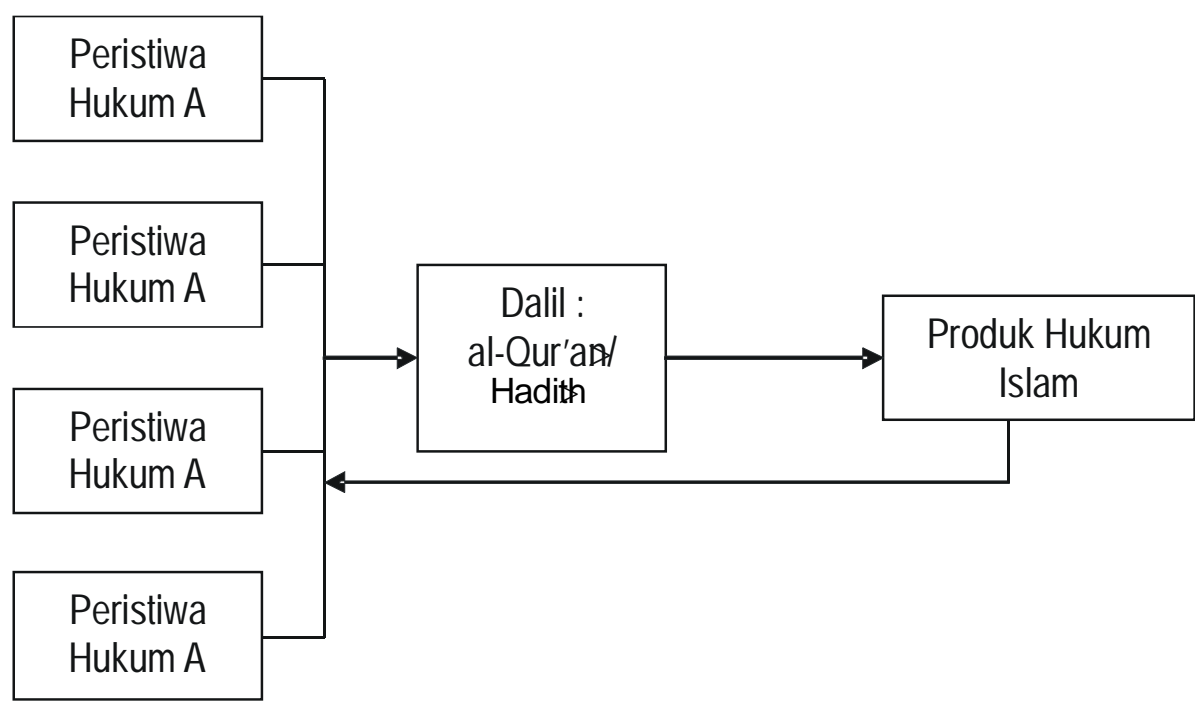

Gambar 2 : Metode Induksi Korespondensi dalam Kajian Keilmuan Hukum Islam

Dengan demikian, keilmuan hukum Islam dapat diperoleh melalui telaah terhadap peristiwa hukum empirik secara parsial, satu persatu, baik dalam bentuk sampel maupun populasi ditinjau berdasar dalil baik al-Qur'an maupun halith selanjutnya dibuatkan ketentuan hukumnya dalam bentuk kesimpulan ide hukum. Pola pikir induktif pada keilmuan hukum

${ }^{15}$ Louay Safi, Ancangan Metodologi Alternatif, terjemahan Imam Khoiri (Yogyakarta: Tiara Wacana, 2001), 113. 
Islam berbeda dengan pola pikir yang sama pada ilmu pengetahuan umumnya. J ika pada ilmu pengetahuan umum pencaharian kebenaran dimulai dari fakta-fakta di lapangan yang kemudian dari berbagai fakta itu dibuat kesimpulan, maka pada keilmuan hukum Islam, pembuatan kesimpulan bukan berdasar 'apa' kata fakta itu, tetapi bagaimana keberadaan fakta itu secara hukum sehingga kesimpulan yang dibuat bukan berdasar pernyataan fakta semata tetapi pernyataan dalil tentang fakta itu, baik dalil al-Q ur'an atau ha्gdith Nabi.

3. Metode IImiah

Kajian keilmuan hukum Islam dapat dikaji dengan menggunakan metode ilmiah. Metode ini merupakan gabungan antara metode deduksi-koherensi dan metode induksikorespondensi, yaitu metode yang di samping berdasar analisa rasional juga fakta empirik di lapangan. Sebagai metode gabungan antara cara berpikir rasional dan empiris, ide tentang kebenaran yang menjadi dasar pengetahuan pada metode ilmiah baru dapat diterima bilamana didukung oleh adanya data di lapangan. Sebaliknya data itu dapat diabstraksi sehingga menjadi suatu konsep ilmu pengetahuan. Metode berpikir yang digunakan pada satu sisi bersifat deduktif dan pada sisi yang lain bersifat induktif. Dengan demikian, metode ilmiah berlandaskan pada koherensi dan korespondensi sekaligus yang kebenaran postulatpostulatnya dibangun di atas dua fondasi ini.

Metode ilmiah ini sangat mirip dengan metode istiqra'stamm yang dikemukakan alShatijbi>Tesis al-Shatibizlapat diringkas sebagai berikut. Aturan-aturan partikular (juz'i) sharisah dibangun oleh hukum-hukum universal (qawanin kulliyah). Hukum-hukum itu diketahui melalui survai komprehensif terhadap pernyataan-pernyataaan shari $̧ a h$. Dengan menggunakan prosedur induksi sempurna (istiqra'tamm) itu, seseorang dapat bergerak dari aturan-aturan partikular kepada hukum-hukum universal sharisah. ${ }^{16}$ Menurut Louay Safi, tawaran metode al-Shatijbi>ini dapat memperluas jangkauan ijtihad dari keterbatasanketerbatasan qiyaspartikular kepada suatu proses komprehensif di mana induksi dan deduksi digunakan sekaligus. Induksi memungkinkan kita bergerak dari partikular kepada general, sebaliknya deduksi bergerak dari general kepada partikular. ${ }^{17}$ Berkenaan dengan ini, M. Yasir Nasution menyatakan:

“.... H ukum Islam merupakan hasil dari kegiatan deduktif (istinbatilypara ilmuan dari alQur'aß dan hadith. Akan tetapi, dalam kenyataannya tidaklah selalu demikian. Para ilmuan itu juga mempertimbangkan kenyataan-kenyataan dan nilai-nilai yang hidup di tengah-tengah masyarakat (al-'urf). Kenyataan dan nilai-nilai itu dihargai sebagai sumber dan dalil setelah mendapat pembenaran dari al-Qur'aß. Dengan cara ini tampak suatu proses induktif (istiqrai). Perumusan norma-norma dan kaedah-kaedah hukum dari alQ ur'aß dan hądith, dengan demikian, merupakan proses kombinasi deduksi dan induksi. Dengan cara ini, maka suasana kesenjangan antara hukum Islam dan perkembangan masyarakat semestinya tidak terjadi". ${ }^{18}$

\footnotetext{
${ }^{16}$ Ibrahim bin Musaral-Shatibi>al-M uwafaqatfi Usyllsal-Shari'æah, juz II (B eirut: Dasal-Ma'rifah, tth.), 29-39.

${ }^{17}$ Louay Safi, Ancangan, 113.

${ }^{18}$ M. Yasir Nasution "IAIN dan Kajian Hukum Islam di Abad Modern : Peluang dan Tantangan" dalam Syahrin H arahap (ed.), Perguruan Tinggi Islam di Era G lobalisasi (Yogyakarta: Tiara Wacana Yogya, 1998), 101.
} 
Metode ini berada pada tataran empirik sensual dan empirik logik menggunakan logicoverifikasi yang menggunakan proposisi atau konstruk sebagai landasan teoritik pengkajian dalam rangka memperoleh pengukuran kebenarannya. Selanjutnya lihat gambar berikut:

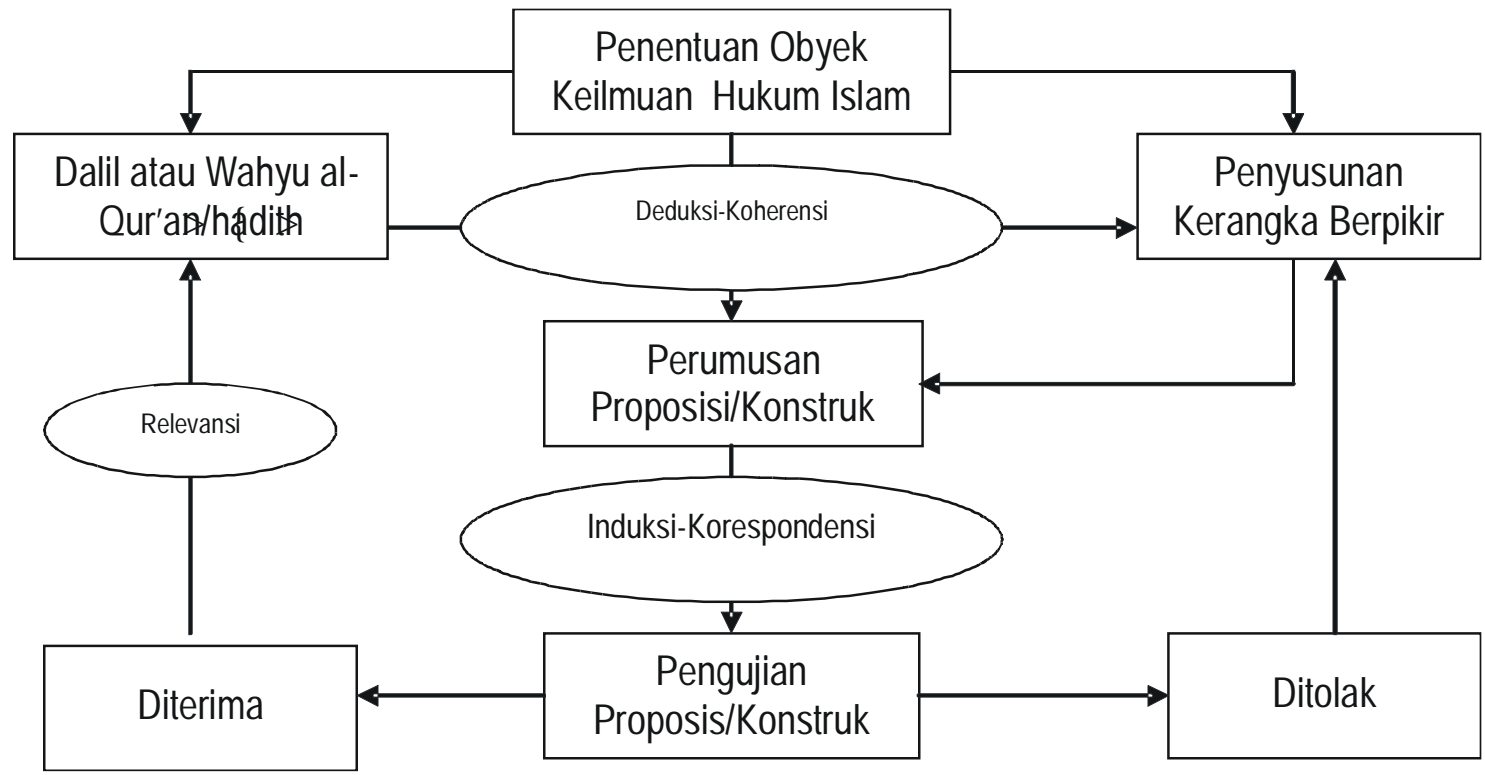

Gambar 3 : Metode Ilmiah Kajian Keilmuan H ukum Islam ${ }^{19}$

Pengkajian keilmuan hukum Islam, yang berasal dari peristiwa-peristiwa hukum empirik dalam rangka untuk menganalisis produk hukum dan teori atau dalil yang mendasarinya, dapat dilakukan melalui langkah-langkah berikut:

a. Menentukan obyek kajian hukum Islam berupa pertanyaan mengenai obyek materia hukum Islam yang jelas batas-batasnya serta dapat diidentifikasikan faktor-faktor yang terkait di dalamnya. Persoalan yang menyangkut obyek ini ditentukan secara rinci dan jelas sehingga diketahui esensi dan eksistensinya.

b. Penyusunan kerangka berpikir baik dengan pengajuan proposisi yang merupakan argumentasi yang menjelaskan hubungan yang mungkin terdapat antara berbagai faktor yang saling mengkait dan membentuk konstelasi permasalahan atau dengan kontruks sebagai landasan teoritik. Kerangka berpikir dalam bentuk proposisi ataupun konstruks ini disusun secara rasional berdasarkan premis-premis ilmiah yang telah teruji kebenarannya dengan memperhatikan dalil hukum (wahyu) dan faktor-faktor empiris atau landasan teoritik yang relevan dengan permasalahan. Perumusan kerangka pikir berdasar teori yang berasal dari khazanah pengetahuan ilmiah yang dipilih secara seksama dan dianggap relevan dengan masalah hukum yang dikaji. Teori ini dapat berupa dalil al-Q ur'an, hadith, atau pendapat ulama. Dalam hal ini digunakan pola pikir deduksi-koherensi.

c. Perumusan proposisi yang merupakan pernyataan sementara atau dugaan terhadap pertanyaan yang diajukan yang materinya merupakan kesimpulan dari kerangka berpikir yang dikembangkan. Proposisi dalam kajian keilmuan hukum Islam, berbeda dengan yang

${ }^{19}$ Bandingkan dengan model logika ilmiah yang dikemukakan J ujun S. Suriasumantri dalam Filsafat IImu : Sebuah Pengantar Populer (J akarta: Bulan B intang, 1990), 129. 
digunakan dalam penelitian ilmiah umumnya, tidak dimaksudkan untuk menguji kebenaran teori atau dalil yang digunakan, tetapi untuk mencari jawaban sementara apakah masalah hukum yang terjadi sesuai dengan ketentuan dalil (teori) atau tidak.

d. Pengujian proposisi yang merupakan pengumpulan fakta-fakta yang relevan dengan proposisi yang diajukan untuk memperlihatkan apakah terdapat fakta-fakta yang mendukung proposisi tersebut atau tidak. Pola pikir yang digunakan adalah induksikorespondensi dengan menelaah kasus-kasus hukum spesifik yang terjadi di lapangan dengan menelitinya secara detail dengan melakukan verifikasi.

e. Penentuan apakah proposisi yang digunakan diterima atau ditolak. Proposisi dinyatakan diterima apabila terdapat kesesuaian antara fakta di lapangan dengan ketentuan dalil hukum dan dinyatakan ditolak apabila ternyata terdapat kesenjangan antara ketentuan dalil hukum dengan peristiwa yang terjadi. Dalam hal ini, keputusan hukum sah atau tidaknya suatu peristiwa tergantung pada ada atau tidak adanya kesesuaian (relevansi).

f. Penarikan kesimpulan yang merupakan penetapan status hukum peristiwa yang sedang dikaji.

Dengan menggunakan metode ilmiah di atas, keilmuan hukum Islam di Fakultas Syari'ah dapat dikembangkan dengan melibatkan teori, konsep, dalil, norma hukum dan mengaitkannya dengan fakta empirik. Pengkajian keilmuan hukum Islam dengan pendekatan ilmiah, sebagai telah dijelaskan di atas, dapat dilakukan meskipun pada awalnya bukan suatu yang mudah. Louay Safi, dalam bukunya Ancangan M etodologi Alternatif, menyatakan bahwa salah satu persoalan pelik yang dihadapi oleh ilmu Islam - termasuk keilmuan hukum Islam - modern yang masih dalam tahap embrionalnya merupakan akibat langsung dari tidak adanya definisi yang pasti tentang hubungan antara akal dan wahyu. Melalui pendekatan ilmiah diharapkan definisi tentang hubungan akal dan wahyu itu dapat dijembatani sehingga menghasilkan konsep yang padu. Selanjutnya, dengan mengutip Muhammad M. Amziyan, Louay menyatakan perlunya mentransendensikan definisi ilmu posifistik untuk satu tujuan yaitu menggabungkan wahyu ke dalam wilayah ilmu pengetahuan secara komprehensif di mana nilai-nilai maupun konsep Q ur'ani digunakan untuk penelitian ilmiah. ${ }^{20}$

Penelaahan konsep hukum secara faktual dapat memberikan kesempatan kepada keilmuan hukum Islam untuk meninggalkan kesan bahwa perkembangan hukum (baik Islam maupun konvensional) selalu berada di belakang masyarakat pelaksana hukum yang selalu dinamis dan berubah secara cepat. Kesan negatif yang disandangkan pada hukum ini akan berdampak pula pada keilmuan hukum dengan teori-teori baku yang sejak lama digunakannya. Dalam hukum Islam, kajian terhadap hukum dilakukan melalui ijtihad dengan metode-meto de

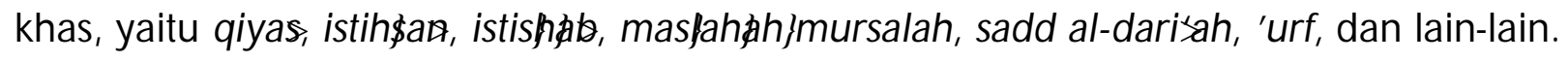
Penggunaan metode-metode ini telah menghasilkan banyak produk hukum dan diakui oleh umat Islam sebagai metode yang valid, meskipun untuk penggunaan beberapa metode terjadi perbedaan pendapat.

Metode ilmiah dijadikan sebagai alternatif pengembangan keilmuan hukum Islam

${ }^{20}$ Louay Safi, Ancangan, 28. 
manakala hukum itu tidak sekedar sebuah produk hukum tetapi sudah menjadi bagian dari ilmu pengetahuan, yaitu ilmu pengetahuan hukum Islam yang dalam penelitian ini disebut dengan keilmuan hukum Islam. Penggunaan metode ilmiah dikarenakan sebagai sebuah ilmu, keilmuan hukum Islam harus memenuhi standar ilmiah yang diukur dengan menggunakan prosedur dan metode ilmiah. Agar keilmuan hukum Islam dapat dianalisis secara ilmiah, maka harus terpenuhi di dalamnya ciri-ciri metode ilmiah yaitu:

a. Memperoleh keterangan yang cukup dan teliti. Eksplanasi keilmuan hukum Islam dilakukan secara memadai sehingga mencakup seluruh atau sebagian besar aspek yang terdapat di dalam klas-klas dan sub-sub klasnya, dikaji secara cermat dan teliti sehingga bersifat valid dan terhindar dari kesalahan dalam analisis ataupun penggunaan metode analisis yang digunakan.

b. Menggunakan pemikiran yang logis dan teratur. Telaah keilmuan hukum Islam dilakukan secara logis, rasional, sesuai dengan tata aturan pemikiran yang lurus. Penggunaan logika baik yang bersifat induktif maupun deduktif diperlukan agar terjadi keteraturan berpikir dalam menganalisis sehingga terhindar dari kesalahan dalam pembuatan kesimpulan. Di samping itu, keteraturan dan keruntutan berpikir diperlukan agar penjelasan mudah dipahami karena dipaparkan secara runtun dan teratur.

c. Menyusun pengetahuan secara sistematis. Disiplin keilmuan hukum Islam disusun secara sistematis, maksudnya antara satu bahasan dengan bahasan berikutnya dilakukan secara runtun sehingga tidak terjadi tumpang tindih antara satu bahasan dengan bahasan yang lain itu. Sistematisasi pembahasan dapat mempermudah dan memperlengkap materi kajian.

d. Membatasi masalah dengan garis-garis yang tegas. Masalah-masalah yang dikaji dalam keilmuan hukum Islam dianalisis dengan mengklasifikasi satu persoalan dengan persoalan lain secara tegas.

e. Menemukan hukum-hukum, prinsip-prinsip umum sebagai suatu teori dasar yang dapat dipercaya untuk digunakan di masa depan. Prinsip-prinsip umum yang dimiliki oleh keilmuan hukum Islam dapat dijadikan sebagai teori dasar untuk pengembangan keilmuan hukum Islam antara lain melalui metode verifikasi yang diharapkan dari itu dapat meprediksi peristiwa hukum pada masa yang akan datang.

f. Menguji dan menunjukkan pokok-pokok dari penemuan-penemuan.

Verifikasi tersebut dimaksudkan sebagai pengujian dan telaah ekploratif untuk melakukan penemuan-penemuan produk hukum tentang peristiwa-peristiwa yang terjadi di kalangan umat Islam.

4. Metode Fenomenologis.

Di samping metode ilmiah, telaah keilmuan hukum Islam dapat menggunakan metode fonomenologis. Dibanding metode ilmiah, metode kedua ini lebih jauh dalam mengkaji suatu obyek. Metode fonomenologi berusaha memperoleh gambaran yang lebih utuh dan fundamental tentang fenomena keilmuan hukum Islam dari pada metode ilmiah. Metode fenomenologi - yang diilhami oleh cara pendekatan filosofis yang dikembangkan oleh Edmund Husserl - ini berupaya untuk memperoleh esensi keilmuan hukum Islam untuk mengembalikan hukum Islam yang bersifat historis-empiris ke pangkalannya agar tidak terlalu 
jauh melampaui batas-batas kewenangannya. Fenomenologi berusaha memperoleh gambaran yang utuh serta struktur fundamental keilmuan hukum Islam secara umum (universal, transendental, inklusif) bukan gambaran keilmuan yang bersifat partikuler-eksklusif. ${ }^{21} \mathrm{~J} \mathrm{ika}$ dalam studi keilmuan hukum yang bersifat historis empiris, para peneliti cenderung bersikap netral (value-neutral), maka pendekatan fenomenologi lebih bersifat value-laden (terikat oleh nilai-nilai kegamaan yang dipercayai dan dimiliki oleh para pengikut agama yang ada. ${ }^{22}$

Karakteristik utama metode fenomenologis adalah di dalamnya terdapat empat kebenaran, yaitu kebenaran empirik sensual (yang ditangkap oleh panca indera), kebenaran empirik logik (yang dihasilkan akal/rasio/pikiran), kebenaran empirik etik (idealisasi realitas), dan kebenaran empirik transendental (kebenaran yang berkaitan dengan keyakinan atau ketuhanan) ${ }^{23}$

Kebenaran empirik sensual diperoleh melalui panca indera yang menangkap obyek empirik pengetahuan. Kebenaran hukum Islam secara empirik sensual berkenaan dengan upaya manusia dalam memahami obyek atau kejadian hukum di kalangan masyarakat muslim. Dengan mengamati, mengobservasi, dan meneliti peristiwa hukum Islam di kalangan masyarakat, kita dapat memperoleh gambaran tentang bagaimana hukum berfungsi dalam mengatur mereka. Peristiwa hukum itu ditelaah secara empirik-inderawi sehingga diketahui kebenarannya. Tentang kebenaran ini, Hamid Hasan Bilgrani dan Sayid Ali Asyraf menyatakan:

“Konsep ilmu pengetahuan yang purna-demensional ini diawali dengan pengetahuan tentang benda-benda yang dapat dipersepsi, kemudian mentransendensikan bidang ini dan memasuki bidang orang-orang mukmin. Terainnya ilmu pengetahuan ini merupakan tujuan setiap orang mukmin sebagai tujuan sentral dan prinsipal yang berfungsi bagi hidupnya". ${ }^{24}$

Kebenaran empirik logik diperoleh melalui pemikiran logis yang didasarkan pada data empirik, bukan logika murni umumnya yang berdasar premis-premis tertentu baik premis mayor maupun premis minor meskipun tanpa dukungan data di lapangan. Kebenaran keilmuan hukum Islam yang diusung oleh empirik logik dimulai dengan pemikiran logis hukum Islam yang kemudian dicarikan bukti-buktinya di lapangan. J ika premis-premis yang terdapat pada pemikiran hukum itu logis dan sejalan dengan bukti-bukti empirik di lapangan, maka kebenarannya dapat diterima. Kalau tidak, maka tidak dapat diterima.

Kebenaran empirik etik berkenaan dengan idealisasi realitas, yaitu kebenaran suatu obyek dilihat dari segi kebenarannya secara etis. Kebenaran keilmuan hukum Islam tidak semata-mata dikaji berdasar teori-teori yang mendasarinya tetapi ditelaah pula dari segi nilainilai etis yang terdapat di dalamnya. Meskipun, di kalangan para ahli terjadi perbedaan pendapat apakah bidang hukum dapat ditelaah bersamaan dengan etika atau tidak. Jika

\footnotetext{
${ }^{21}$ Bandingkan dengan Amin Abdullah, Studi Agama: Normativitas atau Historisitas?, cet. 3 (Yogyakarta: Pustaka Pelajar, 2002), 11.

${ }^{22}$ Ninian Smart, The Science of Religion and Sociology of Knowledge: Some Methodological Questions (N ew J arsey: Princton University Press, 1973), 378.

${ }^{23}$ Noeng Muhadjir, M etodologi Penelitian Kualitatif (Yogyakarta: Rake Sarasin, 2002), 13-34.

${ }^{24}$ Hamid Hasan Bilgrani dan Sayid Ali A syraf, Konsep Universitas Islam (Yogyakarta: Tiara Wacana, 1989), 5.
} 
dilihat dari kaca mata filsafat ilmu yang membagi telaah ilmu pengetahuan berdasar tiga kategori; ontologi, epistemologi, dan aksiologi, maka keilmuan hukum Islam tidak dapat dilepaskan dari aspek nilai termasuk nilai etis.

Kebenaran empirik transendental merupakan kebenaran yang berkaitan dengan keyakinan atau ketuhanan. Kebenaran fenomenologi empirik transendental ini sangat inheren dengan keilmuan hukum Islam, suatu pengetahuan yang berasal dan bersumber dari Allah sebagai Shan' (pembuat dan penetap hukum). Berbeda dengan hukum positif $B$ arat, hukum Islam tidak dapat dilepaskan dari sifat transendental. Pada kajian ini, transendental tidak dipahami secara murni terlepas dari sifat empirik sehingga fenomena yang mengemuka adalah telaah keilmuan hukum Islam berdasar fakta hukum Islam yang bersifat empiris yang dipadukan dengan ketentuan wahyu baik dalam al-Qur'an (al-wahy al-matlu)maupun hiकdith (al-wahy ghayr al-matlup.

Melalui meto de fenomenologis diharapkan kajian keilmuan hukum Islam dapat terlepas dari kesenjangan antara positivisme logis dengan etos Islam, sebagai dikhawatirkan Muhammad Arif, ${ }^{25}$ sehingga diperlukan peran sarjana-sarjana muslim dalam rangka rekonsiliasi nilai-nilai Islami dengan metode logika positivistik. Keempat kebenaran yang menjadi dasar metode fenomenologis di atas secara integral dapat digunakan untuk menganalisis keilmuan hukum Islam dengan melibatkan kebenaran yang diperoleh dari indera, logika, etika, dan wahyu sebagaimana terlihat pada gambar berikut:

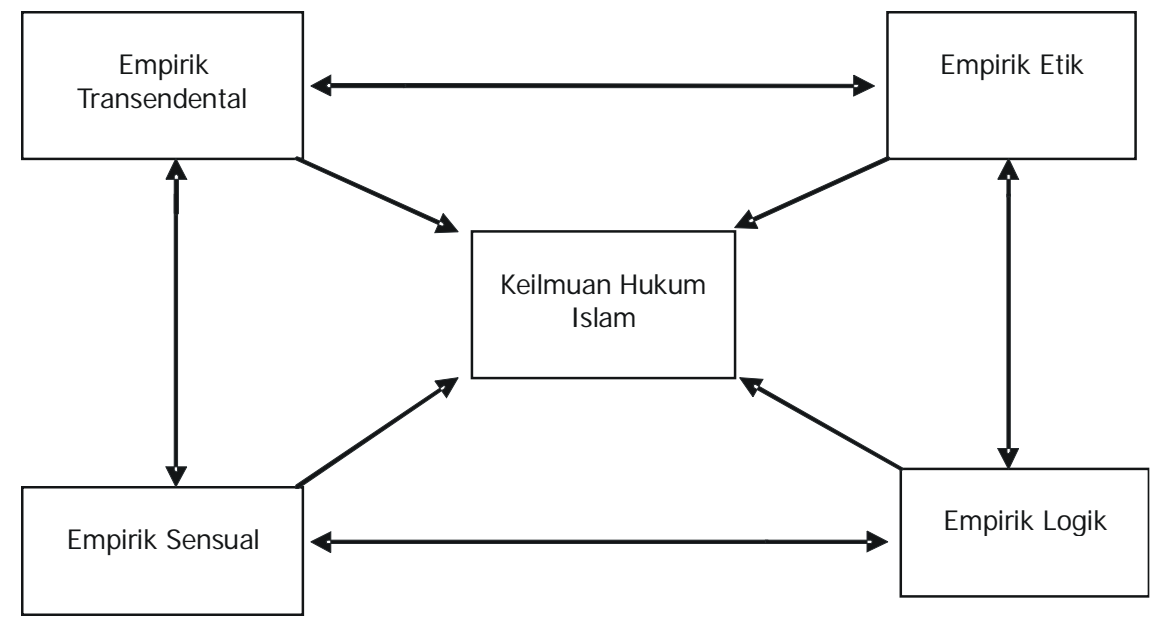

Gambar 4 : Skema Aplikasi Metode Fenomenologis pada Keilmuan Hukum Islam

Pada gambar di atas terlihat bahwa keilmuan hukum Islam Fakultas Syari'ah dapat dikaji dengan metode fenomenologis melalui pendekatan empirik sensual, empirik logik, empirik etik, dan empirik transendental. Keempat pendekatan (kebenaran) di atas dapat digunakan secara interelasif dalam pengkajian keilmuan hukum Islam. Keempatnya senada dengan analisis H amid Hasan Bilgrani dan Sayid Ali Asyraf tentang beberapa aspek dalam cara berpikir,

${ }^{25}$ Muhammad Arif, The Islamization of Knowledge and Some Methodological Issues in Paradigm Building : The General Case of Social Science with a Special Focus on Economics, American J ournal of Islamic Social Science (4: 1), 1987, 51 dikutip oleh Louay Safi. Lihat Louay Safi, Ancangan, 24. 
yaitu aspek etik, aspek perseptual, aspek historik, aspek psikologik, aspek observatif, dan aspek eksperimenta| ${ }^{26}$ atau kebenaran absolut (haq al-yaqin), rasionalisme, atau inferensi dengan penilaian bukti ('ilm yaqia) serta melalui empirisisme ('ayn al-yaqia) menurut Abd al-Rasyid Moten. ${ }^{27}$

5. Metode Struktural Fungsional

Metode ini diperoleh dari teori struktural fungsional yaitu teori yang berpandangan bahwa agama dan kitab sucinya bisa menjadi fungsional ketika agama menjadi norma dalam masyarakat. ${ }^{28}$ Berdasar teori struktural fungsional, hukum Islam diterjemahkan dan diaplikasikan sebagai pranata sosial yang fungsional bagi masyarakat. Hukum Islam tidak sekedar dipahami sebagai firman (khitab) Allah yang berkaitan dengan perbuatan mukallaf atau sekumpulan hukum yang berhubungan dengan perbuatan mukallaf, baik yang terdapat dalam al-Qur'an, hądith atau produk hukum ulama (pendapat ulama yang sejatinya diperoleh melalui pemahaman terhadap al-Qur'an dan halith itu), tetapi hukum itu telah terinternalisasi dalam kehidupan masyarakat muslim dalam bentuk norma atau lembaga hukum.

Keilmuan hukum Islam kategori ini terlihat pada lembaga-lembaga hukum Islam, lembaga-lembaga ekonomi Islam, dan sebagainya yang konsep dasar atau aplikasinya berdasar pada ketentuan-ketentuan hukum Islam. Struktur fungsional keilmuan hukum Islam sebagaimana dimaksud oleh metode ini terkaiterat dengan norma-norma yang terdapat dalam suatu sistem kemasyarakatan yang di dalamnya terdapat beberapa sub sistem, yaitu sub sistem fisik, sub sistem biologis, sub sistem politik, sub sistem ekonomi, sub sistem sosial, sub sistem budaya, sub sistem kesehatan, sub sistem pertahanan keamanan, dan sub sistem hukum. ${ }^{29}$ Keilmuan hukum Islam terinternalisasi dalam suatu masyarakat muslim pada sebagian wilayah sub sistem kemsyarakatan di atas dan menjadi norma kehidupan mereka.

Metode struktural fungsional dapat menggunakan pendekatan sosiologis sebagai obyek forma pengkajian hukum Islam, dengan cara mengkaji fenomena-fenomena hukum yang

\footnotetext{
${ }^{26} \mathrm{H}$ amid Hasan Bilgrani dan Sayid Ali Asyraf menjelaskan tentang posisi al-Qur'an yang merupakan petunjuk dalam hal cara berpikir terutama mengenai tiga aspek pokok ilmu pengetahuan berikut:

[a] Aspek etik, termasuk aspek perseptual dalam ilmu pengetahuan. Aspek ini berkaitan dengan prinsip dasar mengenai keyakinan, perbuatan, dan moralitas baik untuk perorangan maupun kemasyarakatan dengan sistem atau pandangan hidup yang sempurna untuk tercapainya kebahagiaan di dunia dan akhirat.

[b] Aspek historik dan psikologik dalam ilmu pengetahuan yang berkaitan dengan berbagai sikap dan cara berpikir manusia yang mempengaruhi dan menentukan persepsi mereka terhadap kebenaran dan realitas serta tanggungjawab terhadap berbagai konsekuensi yang timbul.

[c] A spek observatif dan eksperimental dalam ilmu pengetahuan. Aspek ini berkali-kali ditekankan oleh para ilmuan sebagai sumber utama untuk memperoleh ilmu pengetahuan tentang benda-benda, hubungan antar benda, dan hubungan antara benda dengan Tuhan (Hamid Hasan Bilgrani dan Sayid Ali Asyraf, Konsep, 4).

${ }^{27} \mathrm{Abd}$ al-Rasyid Moten menyatakan bahwa dalam skema Qur'ani, pengetahuan ('ilm) dicapai melalui wahyu atau kebenaran absolut (hæq al-yaqia), rasionalisme, atau inferensi yang didasarkan pada perimbangan dan penilaian bukti ('ilm yaqia) serta melalui empirisisme dan persepsi, yakni dengan observasi, eksperimen, laporan sejarah, deskripsi pengalaman hidup ('ayn al-yaqia), dan lain-lain. Cara mengetahui yang Islami selaras dengan kebebasan penuh untuk mengalami dan eksperimen serta penelitian rasional dan intelektual dalam lingkaran pengetahuan yang diwahyukan. Lihat dalam Muhammad Arif, The Islamization of Knowledge: Methodology of Research in Political Science, A merican J ournal of Islamic Social Science (7 : 2), 1990, 163. dikutip oleh Louay Safi. Lihat Louay Safi, Ancangan, 25.

${ }^{28}$ Imam Suprayogo dan Tobroni, M etodologi Penelitian Sosial-Agama (Bandung: Remaja Rosdakarya, 2003), 85.

${ }^{29}$ Bandingkan dengan J uhaya S. Praja, Filsafat dan M etodologi IImu dalam Islam (Bandung: Teraju, 2002), 97.
} 
terdapat pada suatu masyarakat dalam perspektif sosiologi. Sosiologi sendiri adalah ilmu yang membahas proses interaksi dalam masyarakat. Sebagai suatu proses interaksi, maka sosiologi membahas : [1] hubungan kerja sama secara homogen maupun secara heterogen yang menyebabkan adanya interaksi, [2] hubungan antagonis secara homogen ataupun heterogen yang menimbulkan permusuhan, pertikaian dan konflik baik dalam skala sederhana maupun skala luas. ${ }^{30}$

Kajian hukum Islam berdasar pendekatan sosiologis ini diperlukan mengingat hukum Islam, sebagaimana hukum pada umumnya, tidak dapat dilepaskan dari kehidupan sosial sebab suatu hukum akan mempunyai kekuatan mengikat baik sebagai pengatur, pengarah, ataupun kontrol apabila diterapkan dalam suatu komunitas tertentu. J ika hukum hanya berada pada tataran teoretik (law in book) dan tidak pada tataran aplikasi (law in action) sebagaimana terjadi dalam masyarakat, maka tujuan dan falsafah ditetapkannya hukum sulit untuk diterapkan.

Dalam setiap masyarakat senantiasa terdapat kepentingan-kepentingan yang harus dipenuhi. Pemenuhan kepentingan tersebut dilakukan dengan berbagai cara dan melalui kaedah-kaedah tertentu. Dalam upaya menghindari adanya benturan antar kepentingan tersebut, biasanya kaedah-kaedah dihimpun dalam beberapa lembaga sosial sesuai dengan bidang-bidang kehidupan yang ada. Dengan demikian, suatu lembaga sosial merupakan himpunan kaedah-kaedah dari segala tingkatan yang berkisar pada suatu kepentingan pokok dalam suatu masyarakat. Kepentingan itu mungkin berada pada bidang kehidupan fisik, biologis, politik, ekonomi, sosial, budaya, kesehatan, pertahanan, keamanan, dan hukum.

Aspek-aspek yang perlu diperhatikan ketika meninjau materi keilmuan hukum Islam berdasar pendekatan sosiologis adalah:

a. Paradigma fakta sosial yang berkenaan dengan sistem sosial dan struktur sosial (bersifat eksternal) yang secara dominan dapat mempengaruhi prilaku manusia termasuk di bidang hukum Islam. Dalam sistem dan struktur sosial itu terdapat dimensi fungsional yang bersifat positif dan dimensi konflik yang cenderung bersifat negatif.

b. Paradigma definisi sosial yang menitik beratkan pada tindakan sosial berdasar kesadaran seseorang (internal) yang juga dapat mempengaruhi prilakunya termasuk di bidang hukum Islam. Tindakan sosial itu bersumber dari daya inovasi, kreasi, dan seleksi yang terdapat dalam diri manusia.

c. Paradigma perilaku sosial yang menitik-beratkan pada dunia empiris yang terlihat pada prilaku manusia melalui interaksi sosial mereka. Paradigma ini sebagai antitesa dari dua paradigma sebelumnya karena sistem dan struktur sosial ataupun subyektifitas (definisi) sosial dinilai jauh dari realitas sosial yang sebenarnya. Prilaku manusia sebagaimana terlihat dalam kehidupan keseharian menjadi titik sentral peradigma ini.

J ika diperhatikan aspek-aspek yang menjadi obyek forma sosiologis keilmuan hukum Islam, yakni paradigma fakta sosial, definisi sosial, dan prilaku sosial, maka internalisasi norma hukum dalam kehidupan masyarakat terjadi baik karena sistem sosial dan struktur sosial

${ }^{30}$ Abdul Rozak, Cara Memahami Islam: M etodologi Studi Islam, 144. 
(bersifat eksternal) yang secara dominan dapat mempengaruhi prilaku manusia, tindakan sosial berdasar kesadaran seseorang (internal) yang juga dapat mempengaruhi prilakunya, maupun dunia empiris yang terlihat pada prilaku manusia melalui interaksi sosial mereka.

\section{Prosedur Analisis Pembelajaran Keilmuan Hukum Islam}

Kegiatan analisis pembelajaran keilmuan hukum Islam dimaksudkan untuk mengidentifikasi kebutuhan-kebutuhan pembelajaran keilmuan itu dalam rangka untuk mencapai tujuannya. Pencapaian tujuan pembelajaran tersebut didahului dengan analisis kompetensi yang harus dicapai mahasiswa sebagaimana dirumuskan dalam kurikulum Fakultas Syari'ah. Analisis tersebut merupakan proses menjabarkan kompetensi menjadi sub-sub kompetensi yang tersusun secara logis dan sistematik. Prosedur analisis mata kuliah keilmuan hukum Islam dapat dilakukan dengan tiga pendekatan, yaitu: analisis taksonomi, analisis kompetensi, dan pengolahan informasi sebagaimana terlihat pada gambar berikut:

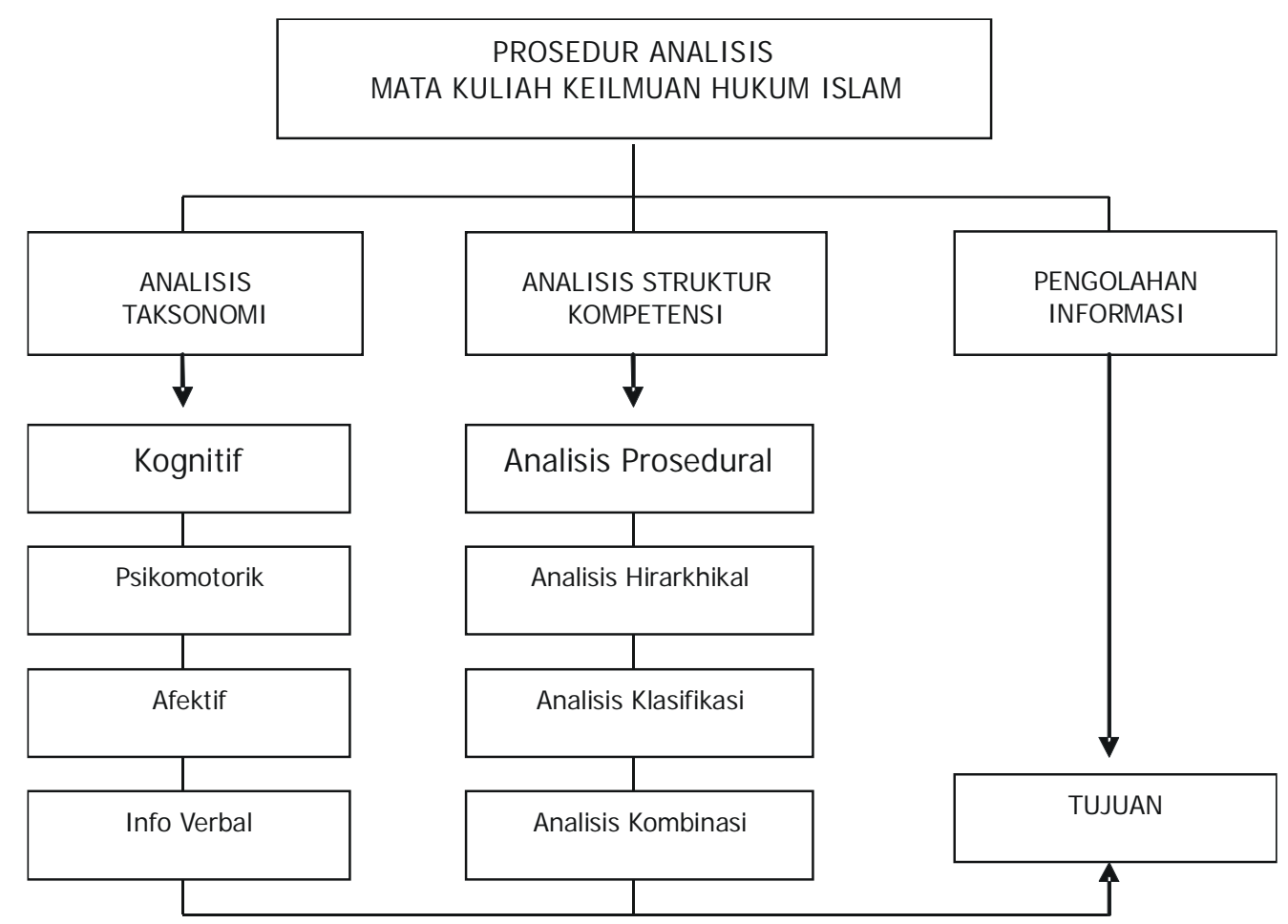

Gambar 5 : Prosedur Analisis Pembelajaran Keilmuan H ukum Islam ${ }^{31}$

Analisis taksonomi dilakukan dengan memperhatikan empat kemampuan yang harus dicapai dalam pengkajian keilmuan hukum Islam, yaitu kemampuan kognitif, psikomotorik, afektif, dan info verbal. Kemampuan kognitif tampaknya merupakan wilayah paling banyak bagi kajian keilmuan hukum Islam yang menuntut penguasaan seperangkat keilmuan hukum Islam dengan berpikir sistematis, logis, dan rasional. Kemampuan motorik menghendaki penguasaan keterampilan dalam bidang-bidang yang berkaitan dengan hukum Islam di samping keterampilan-keterampilan teknis keseharian. Kemampuan afektif merupakan kemampuan yang

${ }^{31}$ Bandingkan dengan Dwi Agus Sujimat "Pengembangan Satuan Acara Perkuliahan" dalam Tim Penyusun IAIN Sunan Ampel, Panduan Satuan Acara Perkuliahan (Surabaya: IAIN Sunan Ampel, 2007), 10-11. 
harus dimiliki berkenaan dengan sikap dalam mengaplikasikan konsep-konsep hukum Islam, termasuk penghayatan terhadapnya. Kemampuan info verbal terkait dengan keterampilan dalam mengemukakan argumentasi secara verbal, menyampaikan kepada masyarakat konsep-konsep hukum Islam yang telah dipelajari.

Analisis struktur kompetensi berkenaan dengan empat aspek, yaitu:

1. Analisis prosedural, yaitu penganalisaan mata-kuliah-mata kuliah keilmuan hukum Islam dengan kompetensinya masing-masing dengan satu seri urutan penampilan, tidak ada yang menjadi kompetensi prasyarat bagi kompetensi yang lain. Masing-masing berdiri sendiri, meskipun dapat dilakukan secara berurutan. Dalam hal ini, satu mata kuliah dapat dipelajari meskipun seorang mahasiswa belum mempelajari mata kuliah yang lain.

2. Analisis hirarkhikal, yaitu penganalisaan mata kuliah-mata kuliah keilmuan hukum Islam di mana satu kompetensi hanya dapat dipelajari jika kompetensi yang lain sudah dipelajari dan dikuasai. Analisis ini dilakukan karena terdapat mata kuliah berjenjang, yang satu menjadi prasyarat bagi mata kuliah yang lain. Misalnya, mata kuliah asas, pokok, dan terapan. Ketika mahasiswa akan memprogram mata kuliah perkawinan Islam di Indonesia, maka terlebih dahulu ia harus lulus mata kuliah asas-asas hukum perkawinan Islam dan hukum perkawinan Islam.

3. Analisis klasifikasi, dilakukan dengan cara mengelompokkan mata kuliah-mata kuliah yang tidak memiliki ketergantungan satu dengan yang lain. Masing-masing mata kuliah dikelompokkan sesuai dengan kompetensinya; dasar, utama, atau pendukung tanpa harus mendahulukan mata kuliah prasyarat dari mata kuliah pokok.

4. Analisis kombinasi, yaitu pengalisaan mata kuliah dengan menggunakan analisis prosedural, analisis khirarkhikal, dan analisis klasifikasi secara bersamaan, atau menggabungkan ketiga macam analisis tersebut untuk pengkajian mata kuliah-mata kuliah keilmuan hukum Islam.

Gambar di atas menunjukkan bahwa setelah dilakukan analisis taksonomi dan analisis struktur kompetensi dilanjutkan dengan pengolahan informasi. Dengan kata lain, kompetensi yang hendak dicapai baik berupa kognitif, afektif, psikomotorik, atau info verbal yang terdapat pada mata kuliah-mata kuliah keilmuan hukum Islam diidentifikasi dan diurutkan kompetensi mana yang menjadi prioritas pertama, kedua, dan seterusnya. Jika prioritas utama adalah kompetensi kognitif, maka silabi mata kuliah diarahkan semaksimal mungkin pada wilayah itu, demikian pula kompetensi-kompetensi yang lain. Selanjutnya, mata kuliah-mata kuliah yang terdapat dalam kurikulum dianalisis dengan memperhatikan analisis kompetensi, yaitu analisis prosedural, analisis khirarkhikal, analisis klasifikasi, dan analisis kombinasi. Keempat bentuk analisis ini digunakan sesuai dengan kebutuhan. Informasi yang ada diolah sedemikian rupa menggunakan metode-metode pengolahan informasi. Melalui semua proses itu diharapkan akan tercapai tujuan yang telah ditetapkan.

\section{Penutup}

Beberapa metode analisis keilmuan yang dijelaskan di atas baik metode deduksi-koherensi, induksi-korespondensi, metode ilmiah, metode fenomenologis, maupun struktural fungsional dapat digunakan untuk menganalisis keilmuan hukum Islam sebagai suatu disiplin ilmu 
pengetahuan yang seharusnya memenuhi standar ilmiah sebagaimana ilmu pengetahuan pada umumnya. Perlu disadari bahwa metode-metode di atas tidak dimaksudkan sebagai bagian dari metode ijtihad dalam penetapan hukum Islam seperti yang dipraktekkan para mujtahid dalam menetapkan hukum Islam. Sebab, metode-metode penetapan hukum Islam kebanyakan sudah baku ditentukan dalam disiplin ilmu U syl l $\$$ iqh baik melalui kaedah-kaedah kebahasaan maupun kaedah-kaedah shar'iyah. Demikian halnya keempat aspek analisis prosedural, khirarkhikal, klasifikasi, kombinasi tidak dimaksudkan sebagai upaya kajian materi-materi hukum Islam sebagai yang terdapat dalam kitab-kitab fiqih tetapi lebih ditekankan pada aspek pembelajaran sehingga diharapkan aktifitas pembelajaran dapat berhasil secara maksimal.

\section{Daftar Rujukan}

Abdullah, Amin. Studi Agama: Normativitas atau Historisitas?, cet. 3. Yogyakarta: Pustaka Pelajar, 2002.

Arif, Muhammad. The Islamization of Knowledge and Some Methodological Issues in Paradigm Building : The General Case of Social Science with a Special Focus on Economics, American J ournal of Islamic Social Science (4:1), 1987.

- - - - - . The Islamization of Knowledge: Methodology of Research in Political Science, American J ournal of Islamic Social Science (7:2), 1990.

Bilgrani, Hamid H asan dan Sayid Ali Asyraf. Konsep Universitas Islam. Yogyakarta: Tiara Wacana, 1989.

al-Faruqi, Ismail R. Islamization of Knowledge: General Principles and Work Plan. Herdon: VAIIT, 1987.

Gurvitch, G eorges. Sosiologi Hukum, terjemahan. J akarta: Bharata, 1988.

J amal al-Din, Abural-Fadls. Lisan al-'Arab, jilid XIII. B eirut: Dasal-Kutub al-'IImiyah, th.

Khallaf, 'A bd. Al-Wahhab. 'IIm Usyllsal-Fiqh.(Beirut: Dasal-Q alam, 1978.

Mahmasani, Subhi "Adaptation of Islamic J urisprudence to Modern Social Needs" dalam J ohn J. Donohue dan J ohn L. Esposito (ed.). Islam in Transition Muslim Perspectives. New York: Oxford University Press, 1982.

Ma'luf, Luis. al-M unjid. Beirut: Matha'ah al-Katulikiæah, tth.

Muhadjir, Noeng. M etodologi Penelitian Kualitatif . Yogyakarta: Rake Sarasin, 2002.

Nasution, H arun. Islam Ditinjau dari Berbagai Aspeknya, J ilid I. J akarta: UI Press, 1985.

Nasution, M. Yasir "IAIN dan Kajian Hukum Islam di Abad Modern: Peluang dan Tantangan" dalam Syahrin Harahap (ed.). Perguruan Tinggi Islam di Era Globalisasi. Yogyakarta: Tiara Wacana Yogya, 1998.

Praja, J uhaya S. Filsafat dan Metodologi IImu dalam Islam. Bandung: Teraju, 2002.

Safi, Louay. Ancangan M etodologi Alternatif, terjemahan Imam Khoiri. Yogyakarta: Tiara Wacana, 2001, 113. 
Sujimat, Dwi Agus "Pengembangan Satuan Acara Perkuliahan" dalam Tim Penyusun IAIN Sunan Ampel, Panduan Satuan Acara Perkuliahan. Surabaya: IAIN Sunan Ampel, 2007. al-Shafi'i, Muhammad bin Idris. al-Risalah. Beirut: Dasal-Kutub al-'Ilmiyah, tth. al-Shatijbi, Ibrahim bin Musa>al-M uwafaqatfi Usjulbal-Shari'gh, juz II. Beirut: Dasal-Ma'rifah, th. Smart, Ninian. The Science of Religion and Sociology of Knowledge: Some Methodological Questions. New J arsey: Princton University Press, 1973.

Suriasumantri, J ujun S. Filsafat Ilmu: Sebuah Pengantar Populer. J akarta: Bulan Bintang, 1990. Suprayogo, Imam dan Tobroni. Metodologi Penelitian Sosial-Agama. Bandung: Remaja Rosdakarya, 2003. 